UDC 17.023.32: $[9+159.953+811+008$

DOI: https://doi.org/10.30839/2072-7941.2018.149627

\title{
NATION AS A REFLECTION OF HISTORY, MEMORY, LANGUAGE AND CULTURE
}

\author{
(C) DZVINCHUK, D. I. \\ Ivano-Frankivsk National Technical University of Oil and Gas (Ivano-Frankivsk, \\ Ukraine)
}

E-mail: dzvin56@ukr.net, ORCID 0000-0002-6391-3822

(C) OZMINSKA, I. D.

Ivano-Frankivsk National Technical University of Oil and Gas (Ivano-Frankivsk Ukraine) E-mail: irynaozka@gmail.com, ORCID 0000-0002-2521-8626

The article presents a systematic and detailed account of scholarly developments on the problem of studying the process of nation-building and the role of history, memory, language and culture in reflecting this process. The research reveals that according to the premordialist approach, nations are not formed instantaneously, by the relevant political will or by coincidence of circumstances; the process of creating and consolidating a nation is a long and meaningful one, full of historical events and national cultural tokens. The primordialist concepts are considered unanimous in their recognition of the exceptional significance of psychological factors in the creation of a nation. The creation of a nation involves a sophisticated set of linguistic, religious, ethnic, territorial and myth-household factors that determine the formation of a corresponding type of sociality. The framework of the analytics of the phenomenon of a nation includes not only psychological, but also social, cultural, political, ethical, moral and axiological aspects. The new systembuilding concepts such as solidarity, habitus, plebiscite were added to the discussion of nation. In view of that, it is impossible to carry out the reduction of the phenomenon of a nation to a particular problem field and to localize it to invariant indicators. The formation and optimization of the capitalistic type of social system generates new factors in the interpretation and consolidation of a nation. The reasons for a political defeat in the development of a nation can be referedr to either conscious manipulative techniques, or spontaneous miscalculations. Elaborating the alternative versions of history is nothing but unjustified politicization, implementation of imperial and colonial ambitions, overcoming which is a necessary prerequisite for successful nation-building. The establishment and offsetting of such manipulative influence facilitate the stabilization of the social situation and the resolution of conflicts, and, consequently, contribute to national development. The key point is to establish a nation within the framework of the international and state policy, especially by distinguishing the consolidating and disintegrating influences of state and international politicies on nation-building. The policy of uniting the nation can 
become effective when the important reforms do not deepen the fragmentation of the nation, but rather neutralize it.

Key words: premordialist approach, nation, consolidation, ethnic groups, national communities.

Based on the understanding of the past as a necessary mode of existence of the present, the concept of a nation needs a historical and genetic explanation. The researchers identify the so-called "primordialist" concepts of interpretation of the nation, the famous representatives of which are J. Armstrong, C. Geertz, E. Schils, and others. The essential basis of this approach lies in the belief that nations are not formed instantaneously, by the relevant political will or by coincidence of circumstances. The process of creating and consolidating a nation is long and meaningful, full of historical events and semiotics of national culture. Thus, according to Clifford Geertz, the creation of a nation involves a sophisticated set of linguistic, religious, ethnic, territorial and myth-household factors that determine the formation of a corresponding type of sociality. This sociality is based on the sense of belonging to a community that shares the same values and beliefs, the way of life and motivational stereotypes. E. Smith supports this position as well by describing the language, religion, race, the unity of ethnic origin and common territory as the prerequisites for the formation of a nation. The important aspect in this context is the statement about the spontaneous and unconscious nature of this activity. Therefore, the author states that the community formed spontaneously is more stable and resilient than any other form of political institution and alliance. D. Eller and R. Kaflan, the well-known American researchers of the problem of nation, outlined the following basic principles of primordialism:

The formation of a nation is an a priori process of explication of human sociality which is based on the psychological peculiarities of a particular community, which, in their turn, form a unique habitus in the mental and activity-based dimension of subjectivity.

Psychological archetypes of national consciousness are not subject to rational verification; their action is intuitive and automated. This ensures the unity and solidarity of the national community.

Since the archetype of national consciousness has an impact on the emotional and affective sphere, any kind of social practice is derived from the national perception, caused by it and is essentially relative.

Famous Ukrainian historian Y. Dashkevych is probably the most prominent representative of this school in the Ukrainian discourse on the nation. The history of the Ukrainian people has experienced a range of various ethnic and civilizational clashes and collaborations. But in the end, the affective striving for national unity demonstrates the importance of the nation in the process of selfidentification of individuals. Hence, it becomes a widespread belief that a nation is an organic entity, not an 
artificial one, whose existence is often justified not thank to favourable geopolitical conditions, but in spite of them. Indeed, the discontinuity of the state structure does not yet alleviate the national feeling, as well as the crisis and the poverty of the national culture do not lead to the impoverishment and assimilation of the nation.

By insisting on the primacy of the nation in the procedures for subjective identification, the representatives of this approach express drastically different opinions on the methodological mechanisms of nation-building. Thus, L. Gumilev and L. Zalizniak view the origin of a nation as a socio-biological mechanism identifying social reality and its transformations with the laws of nature. Y. Bromley and A. Ponomariov advocate the opposite view, postulating the evolutionary and historical concept or progressive and cultural one in the interpretation of the analytics of a nation.

In any case, the primordialist concepts are unanimous in their recognition of the exceptional significance of psychological factors in the creation of a nation. Having originated from the Enlightenment and classical ideas of Giambattista Vico about "the spirit of the people" as the supersonic authority of the collective mentality, the emergence of the traditional scientific approach to the study of a nation has taken place. This approach views the nation through the prism of the common ethnic spirit, the psycholinguistic peculiarities of communication and ideological practices that are eventually transformed into a certain type of organization of the daily rituals and political institutions. Subsequently, these universalistic mytho-poetic concepts became the basis for logical rational discourses of cultural anthropology, ethnology and ethnography. Consequently, the framework of the analytics of the phenomenon of a nation includes not only psychological, but also social, cultural, political, ethical, moral and axiological aspects. Later, new system-building concepts such as solidarity, habitus, plebiscite, etc were added to the discourse of a nation.

In view of that, it is impossible to carry out the reduction of the phenomenon of a nation to a particular problem field and to localize it to invariant indicators. The formation and optimization of the capitalistic type of social system generates new factors in the interpretation and consolidation of a nation. Thus, possession of property, as a material heritage, as well as the value of spiritual knowledge and cultural experience, acquires the status of a nation-building factor.

One of the important factors in the nation-building process is the commonality of the territory where the representatives of a certain ethnic group live and if necessary interact with one another. Hence, Benjamin Mueser[1] conducts an analysis of the theory of territorial sovereignty developed by Emer de Vattel. He argues that the notion of territorial sovereignty is groundlessly reduced to the principle of land ownership. Referring to the theories of Christian Wolf and Samuel von Pufendorf, the author believes that it is essential to verify the national unity and ethnic 
affiliation on the grounds of morality as an integral personality. Criticizing the imperial ambitions that hinder natural freedom of community as well as aspirations of livelihood through agrarian strategy, the author on contrary advocates the need for the normative basis of the nation in natural free political unity. That is, inhabiting the same territory is not an inevitable factor of the unification of a nation, but the initial constant of the formation of ideal constructs that implement strategies for unification and synchronization of the community.

National communities are thought to communicate with one another, therefore, to insist on the special status of internal national communication links would be groundless. Andrea Kathleen Talentino [2] challenges the process of nation-building in the context of international politics. She remarks that such nation-building process combines large-scale rhetorical projections and highly mixed practical implications. Declaratively, the national state, represented by the functioning of a particular government, demonstrates considerable optimism about the consolidation of the nation. But, is the experience of political management of the process of establishing a nation effective enough? The author claims that the transformation of political and social interactions is often necessary in post-conflict situations. However, the rupture of cultural patterns and stereotypes complicates and delegitimizes the work of the government to a great extent. Therefore, the implementation of reforms in political and social life is dangerous due to possible fragmentation of power and intensification of conflict-generating tendencies. Thus, in an attempt to unite the nation, certain radical slogans and chants can trigger a tense confrontation or exacerbation of latent conflicts. For instance, in Ukraine, the question of the state language became one of the formal reasons for justifying external aggression. The reasons for such a political defeat in the development of a nation can be referred to either conscious manipulative techniques, or spontaneous miscalculations in the transitive shift. The key point here is a mission to establish a nation within the framework of the international and state policy, namely by distinguishing the consolidating and disintegrating influences of state and international politics on the process of nationbuilding. The policy of uniting the nation can become effective when the important reforms do not deepen the fragmentation of the nation, but rather neutralize it.

The activities of national governments are viewed as challenging from the perspective of formalizing the concept of the Other. The eloquent example of the influence of interaction with the Other on the ideology is found in classical German sociology at the wake of the twentieth century. Michael Bodeman[3] explores this problem, striving to specify the dynamics of the interaction of ethno-national solidarity and race. By referring to the fundamental works on this problem by Werner Sombart, Georg Simmel, Max Weber and Ferdinand Tönnies, the 
author seeks to clarify the specifics of the discussions about the race and the role of Jews in the society of multinational Germany on the threshold of World War I. The prominent intellectuals and scientists of that time may be blamed to a certain extent for the insufficient attention to the negative manifestations of anti-Semitism in the public opinion of the mentioned above period in the history that caused the nationalist madness in the form of the fascism ideology which engulfed Germany along with some other countries. Therefore, any kind of racial, ethnic, national conflicts require a balanced and consistent intellectual analysis and response from the international community. This horrific historical experience has shaped rather stable comprehensive strategies in world politics. The activities of numerous international organizations whose aim is to ensure sustainable peace are thought to be necessary and productive.

When taking into consideration globalization and acceleration of technogenic and civilizational progress, the absence of response to national confrontations and disputes from the world community can lead to unpredictable consequences. Ukraine had to make these abstract theoretical concepts in modern history more specific. It would be difficult to imagine what the course of events in our country in the last years would have been providing that there were no support and appropriate response from the world political community to the external aggression.

Manipulations with the principles of national consciousness and real values, the creation of alternative variants of interpreting historical events, the formation of the image of the threat and an external enemy reduce the delicate balance between nationalization and nationalism. Investigating this problem, Serhii Plokhii [4] cites Ernest Renan, and argues that history in a false interpretation is an important factor in the formation of a nation. Affirming the right of the nation to interpret its own historical events, or creating alternative national histories, is the subject of heated debate among many thinkers. By analyzing the problem of interaction between the Ukrainian and Russian ethnic groups, the author presents the following arguments: "In defining the time frame of Ukrainian history, the new narrative at that time presented the Ukrainian nation as more ancient than the Russian, and thus deserving full support in its quest for sovereign cultural and political development, unhindered by interference from its younger sibling. In order to achieve that goal, the starting point of the narrative had to be moved as far back as possible" [4, c.118]. The alternative version of history created by the Russian Imperial ideology offsets the principles of Ukrainian nationbuilding: "The history of Ukraine should be reconceptualized in order to overcome the limitations imposed on it by the centuries-old national paradigm. This would help integrate the Ukrainian past into the history of eastern Europe and the whole European continent. One would like to believe that the future of Ukraine lies in Europe, but its past should stay where it belongs, in the multiplicity of 
worlds created by civilizational and imperial boundaries throughout the history of the territory known today as Ukraine" [4, c.122].

Thus, elaborating the alternative versions of history is nothing but unjustified politicization, implementation of imperial and colonial ambitions, overcoming which is a necessary prerequisite for the formation of a nation, namely in Ukraine.

Jesenko Tešan [5] has been researching the methodological strategy of nation-building at the time of recovering from the transitional or crisis state, social upheaval and military conflicts. This model makes use of such sociological terms as limitation, mimesis, ritual and manipulation. J. Tešan states: "I argue that institutions, such as a peace treaty, can become disordered not because they are beyond any order, rather because they fixate a wrong attitude and identity at the wrong time and in the wrong way, institutionalizing mimetic modes of behaviour in liminal moments, producing schismogenic identities as a pathological normalcy. In this way, it becomes easier to diagnose several error-substances. Firstly, the condition of institutionalized liminality allows the interactive forces of deconstruction and construction to operate in unison. In principle, once a treaty is signed and ratified, it becomes impossible to change it. Secondly, the process of deconstructing the previous identity and assembling a new identity is assured via a specific instrument postwar consociation - embedded in the signature of a political institution.
Finally, the underlying forces behind the dividing society can be best analyzed by several anthropological concepts like "trickster", "liminality", "mimesis", and "schismogenesis" [5, c.83].

Understanding the logic and mechanisms of manipulation provides us with the opportunity for a reasoned and viable way of overcoming conflicts of different types in divided societies. The author shares an experience of the localization of the conflict in Bosnia and Herzegovina, where the reinterpretation of nationalism is filled with examples of manipulations of public opinion. The author implicitly asserts: "The self and identity are caught in a net of suspended roles associated both with communism and the mimetic violence of nationalism, where such (mis)identification through liminality becomes considered as normal and desirable " [5, c.82]. It sounds logical that the establishment and offsetting of such manipulative influence facilitate the stabilization of the social situation and the resolution of conflicts, and, consequently, contribute to national development.

The imperial ideology takes advantage of the distorted notions of the nation and history. Unfortunately, the current geopolitical situation is full of examples of the implementation of imperial strategies. The problem of spheres of influence, colonization and post-colonial aspirations is extremely important in the modern world. Thus, the Indian researcher Partha Nath Mukherji [6] turns to the issue of a colonial paradigm in interpreting the problem of a nation. According to the author, 
the Europe-centred paradigm of analysts is asserted as universal and invariant when researching a nation. A large number of post-colonial countries, such as India and China, which have undergone the national liberation stages in the struggle for their independence and gained the chance for national self-identification in the existing multinational structure of a sovereign state. This experience proves that roots of the phenomenon of the nation lies deep in civilizational identity, common history and uniqueness of the cultural foundations. The inevitable cultural heterogenetization of Western countries, caused by the expansion of the immigrant labour market, the regime of economic liberalization and the emergence of world trade, can become an upsetting factor in the hegemony of the European paradigm of interpretation, since the Western European culture has shown its inability to assimilate diverse cultural trends and traditions under such pressing circumstances. Accordingly, there is a strategy of changed reality, or the transition from mono-cultural states to the concept and policies of multiculturalism. The author distinguishes between the concepts of "pluralism" and "multiculturalism", taking into account the concept of a national state. The goal of the research is presented by the author as follows: "I do not propose to add to the interminable survey of the variability that exists in this conceptualtheoretical terrain, suffice it to state that: (a) the line of demarcation dividing ethnic group/ethnicity and the nation is very thin, if at all there is a clear one; and (b) the variability in the definitions can be captured under two broad categories: (1) those that regard the nation as independent of the state; and (2) those that regard it as congruent with the state" $[6$, c. 3$]$. However, the post-colonial experience proves that even a long-lasting policy of suppressing national identity is not capable of eliminating the latter. Therefore, the author sees the commonality of culture and the mechanisms of socialization as a factor in the verification of a nation: "I suggest that 'cultural commonality of its members', howsoever defined, is common to all definitions of ethnic group/category. The objective cultural markers for such commonality could be any cultural attribute (religion, language, race, descent/caste, tribe, ethnic minority or any other). The logic of identification of an ethnic group/category lies in the internalisation of cultural attributes and/or values since birth or through long socialisation. Cultural attributes available through ancestry or history, real or imagined, so internalised, provide boundary markers distinguishing ethnic groups/categories from one another. The factors of ascription and/or lasting socialization are the common denominators of ethnic groups /categories" [6, c.17]. That's why, the history, being viewed synchronically and diachronically, is a horizon of establishment of a nation.

The significance of language as one of the most important features of a nation has been speculated by a number of scientists. Since a language is a form of human development, it plays a formative role in the collective life of people, expresses the collective 
experience of the community; it is the creator of a nation, as the language has an impact on the formation and rooting of certain values and meanings. J. Herder was convinced that nations are natural communities and an individual can only thrive in a particular group, culture, or nation, to which they belong.

The commonality of language has always been interpreted as one of the distinguishing factors for the existence of a consolidated nation. Language problems are relevant in any community. They are particularly acute in multi-ethnical communities, where they interweave with the economic, social, political, national, religious and confessional interests of ethnic groups and nationalities. In one-nation states, the status of a language is hardly ever mentioned, because it is a normal phenomenon. Moreover, there is a range of vivid examples in the history of successful countries (Switzerland, Canada) with two or more official languages, and a sufficiently consolidated nation. However, the level of socio-economic development of the country plays an important role here, since the higher the level of welfare of the population, the less the threat to the integrity of the nation with several official languages is.

Language is a component and an essential element of the culture of an ethno-national community. One can even say more: language plays its role in the formation and preservation of civilizations as ultimate results of cultural development, since civilizations are distinguished among others not only due to the distinctive or specific characteristics of the epoch or part of the world and production technologies, they differ mainly in values, mentality, traditions and stereotypes embedded and transmitted by means of the language of a particular nation.

The phenomenon of mentality, which is encumbered in time by the psychological peculiarity of a particular community, its remoteness of events, immutability, and influence on virtually all activities of representatives of the ethnic group, can be traced to a long-term preservation of information in historical time owing to language and other tools. It is thanks to a spoken word that traditions and customs, established patterns of behaviour inherent in humanity or the local community have been preserved. Taken together, all these processes and mechanisms constitute the content of the socio-historical memory of the community, which means that an ethnic group, nation or any other historical community reaches the understanding of its essence through the "recollection" of certain stages of its development having similar features.

However, such a recollection would have been impossible if the social experience of past epochs influencing the self-organization of different communities was not fixed in their historical heritage. The fact that the primary necessary condition for the transfer of information through historical epochs is the awareness of the members of this community of its social and historical experience, and the second (but less important) condition is the material and verbal 
fixation of this experience in written and spoken language.

John Nagle [7] conducted a research on the complexity and ambiguity of the nature of the interaction of national selfidentification procedures with the plans and strategies of civil society. The collapse of European communism provoked legitimate expectations about the return of the postcommunist countries of Eastern Europe to the capitalist Western world. According to the author, the ambiguity of ethnopolitics and demopolitics should be considered as the main contradiction in integration processes. On the one hand, national unity is based on ethnic identity, genetic links, and adherence to traditions. But, in the end, there are reasons to consider these factors as retrospective. After all, demopolitics, on the other hand, is based on the conviction of universal territorial citizenship. That is, the community of actual interaction is more important and indicative than the commonality of history and origin. The author notes that in the Czech Republic the policy towards ethnic groups shows signs of anti-Russian racism and state discrimination. The foreign policy of this country, however, demonstrates high loyalty towards Russia. In Poland and Hungary the rightwing political movements, that promulgate the concepts of ethnic patriotism, intolerance to foreigners as traitors and opponents, have been popular. The activities of the national government proved to be ineffective, so these trends have remained relevant in the current situation. Nevertheless, according to John Nagle, all these national strategies and nationalist tendencies hinder an adequate assessment and response from the leading Western European countries. The latter are much more interested in compatibility of the economy and foreign policy, rather than in the internal intentions of the social life of the countries of the post-communist camp. Ignoring these threats may trigger an alarming increase in the social influence of nationalist movements inside the European Union, and strengthen the ethnopolicy of Haider's party in Austria and Le Pen's in France.

Following the author's opinion, it is necessary to note that the reaction of the European political elite on the increase in popularity of the outright nationalistic movements is far from being preventive; it is a rather weak and less-than-prompt response.

Quentin Duroy [8] strongly criticizes the ideology of market relations, embodied in the concept of neo-liberalism, nominally postulating the principles of equality for all citizens, without racial, ethnic, social or other criteria for discrimination in regard with their membership to any minority. The author supports the arguments about the significant role of ideology of neo-liberalism in the growth of the economic marginalization of the corresponding social classes in the European Union. First and foremost, the implementation of such a policy promotes tension between the national-cultural majority and ethnic minority groups. In the author's opinion, the neoliberal policy of the European Union, which postulates the same goals and strategies, resulted in 
counterproductive achievements. First of all, the creation of preconditions that strengthened the ideological gap between the concepts of the state and the nation. A noticeable consequence of such a mental shift, or reaction to it, was an increase in nationalist and sometimes separatist movements in the contemporary Old World. The author believes that this illogical and promiscuous approach destroys the liberal and social principles of integration, consolidation of national states, and weakens the system of social protection and social stability in the European Union.

Instead of promoting being ethnoculturally neutral, neoliberal policy has weakened the liberal and social foundations of integration and destabilized the system of public social services in Europe and democratic countries. They nourish what Thorstein Veblen (1923, 28) called "unreasonable habits of national thought, fear, hatred, contempt, and obedience." But do we have grounds to assert the contradictions between ethnopolitics and demopolitics as insurmountable? There is an alternative opinion. Bernard Yack [9] considers inexcusable the refusal from ethnic and cultural mythology as means of developing civil nationalism. Analyzing the American version of civil nationalism, the author argues that regardless how popular among Americans, the motives of their union are fundamentally wrong due to the conscious choice and the aspirations commonality. Such a motive in the strategy of developing a nation is considered by the author as a kind of myth, effective on the one hand, and dangerous on the other. Its effectiveness is explained by the implementation of the program of Enlightenment liberalism. The danger of this political myth evolves everincreasing nationalistic political aspirations, one of the evidence of which is the victory in the last presidential election of $\mathrm{D}$. Trump with true nationalistic slogans and masculine presentation strategy.

Anastasia Christou [10] explores the problem of the nation through the concept of masculinity. The researcher is interested, first and foremost, in identifying forms of masculinity in the migration section, provided that the identity is preserved, namely national aspirations, affiliation, nuclear and extended family ties, peculiarities of selfknowledge. In her opinion, social and personal scenarios are the stages of a life cycle, which helps display certain national markers through the contextualization of masculinity at various stages and in different situations. The results of hermeneutic and phenomenological analysis, conducted by A. Cristo, in which she took into account both emotional and affective, and gender-sensitive meanings, serve as a qualitative basis for the discourse of self-consciousness and life-sustaining activities of migrants. The gender relations of the authorities in the national context reveal the specifics of transnational interaction in the modern world.

The interaction of the dominant nation with ethnic minorities should be seen as a dynamic system of creation, self-governance and reproduction of a single social system of the state. This complex interaction 
process includes the following compulsory components presented by O. Rudakevych:

a) tools for ethnic selforganization such as language; ethnic values, symbols, myths, customs, traditions, rituals, stereotypes; ethnic memory, consciousness, selfconsciousness, ethnonym, morality, experience, culture, ethnic picture of the world, ethnic ideology; nepotism, anthropological, racial characteristics of the ethnic group, ethnogenetics; ethnos-adapted landscape, ethnic range, etc .;

b) forms of ethnic selforganization such as tribe, ethnicity, nation; ethnic group, ethnic structure, ethnic association, ethnic community; ethnophor ethnocos, ethnographic group, ethnic minority, ethno-social organism, ethnopolitical organism, superethnic group; ethnic autonomy, etc ;

c) methods of ethnic selfregulation, including ethnic adaptation, ethnocultural transfer; potestarity, ethnocentrism, ethnocracy, ethnopolitics, ethnopolitical management; ethnic conflict, ethnic identity, ethnic tolerance / intolerance, interethnic communication, xenophobia, genetic mechanisms of self-regulation, sociobiological laws;

d) forms of ethnic selfreproduction: ethnic socialization, ethnic culture as a matrix of ethnic reproduction; culture of interethnic communication; biogenetic selfreproduction, sociobiological mechanisms of reproduction;

e) ethnic genesis, selftransformation: anthropogenesis, sociogenesis, ethnogenesis, ethnic regeneration, ethnic development, ethnic adaptation; ethnic separation, ethnic integration, ethnic consolidation; transformation of forms of ethnicity, ethnic modernization, ethnocultural transfer, historical forms of ethnicity" [11, p.3].

So, let's sum up. The basics of the classical, retrospective model of the study of the nation-building processes can be summarized in the following statements:

1. Affiliation to a nation is determined by the commonality of socio-cultural determinants: epics, symbols, language, morals etc.

2. The unity of a nation is achieved owing to a single, usually inherited territory, within which the major part of the implementation of any activity by members of the national community takes place.

3. A significant number of people on the authentic territory is a factor in the traditional model necessary for the verification of the social group in correspondence with the phenomenon of the nation.

4. The presence of a national state and a national government is also an important factor in the stable existence of a nation. This way, a nation can take advantage of acting as a subject of geopolitics.

5. A meaningful communicative field produced by a corresponding nation creates automated mechanisms for empathic interaction between members of the national community.

6. The affiliation of an individual to a nation involves recognition of the value of his personality, his acquiring of the full range of civil rights and obligations, the legitimization of participation in political, economic, 
educational and any other of daily life activities.

The understanding of the nation as an authentic ethnic group with its own history, territory, language and ideological-behavioral habitus is based on the primordialist approach of theoretical analysis. However, at the same time, the idea of the purity of the nation is rather illusory and dangerous considering its explications. Therefore, the theoretical analysis involves the elaboration of a constructive strategy for the interaction of the dominant ethnic group of the national state with other national minorities. Thus, the Ukrainian nation is multi-ethnic in its composition, and differs from the unified national idealization. But the very demographic situation itself is a reality, and it should be taken into account when elaborating the strategy of national development and statebuilding.
Hence, the modern tight and globalized world stimulates the need for the full cooperation of people of different nations, ethnic groups, social level and personal qualities. This plurality of total communication determines the general tendency of postcolonial thinking, one of the most important principles of which is the refusal from the purity and indiscretion of any concept. The methodological aspect of this question is based on the distortion of cartography of thinking processes through the center and periphery, through a single invariant sample, or an imitation template. Thus, the challenge of shifting the focus of research of a nation from the standard understanding of the dominant nation to the political polyethnic community turns into a current problem of studying nations.

\section{REFERENCES}

1. Mueser, B. (2018). The nation and property in Vattel's theory of territory. Global Intellectual History, 3 (2), 137-155. doi: https://doi.org/10.1080/23801883.2018.1450615

2. Talentino, A. K. (2009). Nation Building or Nation Splitting? Political Transition and the Dangers of Violence. Terrorism and Political Violence, 21 (3), 378-400. doi: https://doi.org/10.1080/09546550902950274

3. Bodemann, Y. M. (2010). Ethnos, race and nation: Werner Sombart, the Jews and classical German sociology. Patterns of Prejudice, 44 (2), 117-136. doi: https://doi.org/10.1080/00313221003714338

4. Plokhy, S. (2011). Between history and nation: Paul Robert Magocsi and the rewriting of Ukrainian history. Nationalities Papers, 39 (1), 117-124. doi: https://doi.org/10.1080/00905992.2010.532780

5. Tešan, J. (2017). Defending the Nation from her Nationalism(s). Nationalism and Ethnic Politics, 23 (1), 81-97. doi: https://doi.org/10.1080/13537113.2017.1273681

6. Mukherji, P. N. (2010). Civic-secular and ethnic nationalisms as bases of the nationstate: multiculturalism at the crossroads? Asian Ethnicity, 11 (1), 1-23. doi: https://doi.org/10.1080/14631360903506745

7. Nagle, J. (1997). Ethnos, demos and democratization: A comparison of the Czech Republic, Hungary and Poland. Democratization, 4 (2), 28-56. doi: https://doi.org/10.1080/13510349708403514 
8. Duroy, Q. (2014). Neoliberal Europe: Enabling Ethno-Cultural Neutrality or Fueling Neo-Nationalist Sentiment? Journal of Economic Issues, 48 (2), 469-476. doi: https://doi.org/10.2753/jei0021-3624480221

9. Yack, B. (1996). The myth of the civic nation. Critical Review, 10 (2), 193-211. doi: https://doi.org/10.1080/08913819608443417

10.Christou, A. (2015). Ageing masculinities and the nation: disrupting boundaries of sexualities, mobilities and identities. Gender, Place \& Culture, 23 (6), 801-816. doi: https://doi.org/10.1080/0966369x.2015.1058760

11.Rudakevych, O. (2012). Dialektyka etnichnoi ta politychnoi natsiyi u poli etnichniyi derzhavi. Politychnyi menedzhment, 4-5, 114-120.

ДЗВІНЧУК, Д. І. - доктор філософських наук, професор, директор Інституту гуманітарної підготовки та державного управління, ІваноФранківський національний технічний університет нафти і газу (ІваноФранківськ, Україна)

E-mail: dzvin56@ukr.net, ORCID 0000-0002-6391-3822

ОЗЬМІНСЬКА, І. Д. - кандидат філософських наук, доцент кафедри публічного управління та адміністрування, Івано-Франківський національний технічний університет нафти і газу (Івано-Франківськ, Україна)

E-mail: irynaozka@gmail.com, ORCID 0000-0002-2521-8626

\section{НАЦІЯ ЯК ІСТОРІЯ, ПАМ'ЯТЬ, МОВА, КУЛЬТУРА}

Анотація. У статті подається детальний аналіз наукових розробок 3 проблем становлення нації, а саме процесу національного будівництва та ролі історії, пам'яті, мови та культури у відображенні цього процесу. Дослідження показує, що згідно 3 примордіалістським підходом, нації не утворюються миттєво, за відповідною політичною волею чи збігом обставин; процес створення та консолідації нації є довгим і значущим, наповненим історичними подіями та національними культурними знаками. Примордіалістські концепції залишаються одностайними у визнанні виняткової важливості психологічних чинників у творенні нації.

Автори досліджують складний комплекс лінгвістичних, релігійних, етнічних, територіальних та міфо-побутових факторів, які визначають формування відповідного типу суспільства. Основою аналітики явища нації є не тільки психологічні, а й соціальні, культурні, політичні, етичні, моральні та аксіологічні аспекти. Нові обговорення концепції системи, такі як солідарність, хабітус, плебісцит, були додані до обговорення нації. 3 огляду на це, неможливо здійснити звуження явища нації до конкретної проблемної сфери та локалізувати іiї на інваріантні показники. Формування та оптимізація капіталістичного типу соціальної системи породжує нові чинники в інтерпретації та консолідації нації.

У статті також розглядається побудова нації в контексті міжнародної та державної політики як ключове завдання та з'ясовується консолідуючий та дезінтегруючий впливи державної та міжнародної політики на процес націєтворення. Причини політичної поразки в розвитку нації можна називати або свідомою маніпулятивною технікою, або спонтанним прорахунком. Розробка альтернативних варіантів історії - це не що інше, як невиправдана політизація, реалізація імперських та колоніальних амбіцій, подолання яких $є$ необхідною передумовою успішного державного будівництва. Встановлення та компенсація маніпулятивного впливу сприяють 
стабілізації соціальної ситуації та врегулюванню конфліктів, а отже, - національному розвитку. Ключовим моментом тут $\epsilon$ створення нації в рамках міжнародної та державної політики, особливо шляхом розмежування консолідаційних і дезінтегруючих впливів державної та міжнародної політики на національне будівництво. Політика об'єднання нації може стати ефективною, коли важливі реформи не поглиблюють фрагментацію нації, а лише нейтралізують їі.

Ключові слова: примордіалістський підхід, нація, консолідація, етнічні групи, національні спільноти.

Дзвинчук, Д. И. - доктор философских наук, профессор, директор Института гуманитарной подготовки и государственного управления, Ивано-Франковский национальный технический университет (ИваноФранковск, Украина)

E-mail: dzvin56@ukr.net, ORCID 0000-0002-6391-3822

Озьминская, И. Д. - кандидат философских наук, доцент кафедры публичного управления и администрирования, Ивано-Франковский национальный технический униыверситет (Ивано-Франковск, Украина)

E-mail: irynaozka@gmail.com, ORCID 0000-0002-2521-8626

\section{НАЦИЯ КАК ИСТОРИЯ, ПАМЯТЬ, ЯЗЫК, КУЛЬТУРА}

Аннотация. В статье представлен подробный анализ научных разработок по проблемам становления нации, а именно процесса национального строительства и роли истории, памяти, языка и культуры в отоборажении этого процесса. Исследования свидетельствуют, что согласно примордиалистским подходам, нации не создаются сразу в соответствии с политической волей или совпадением обстоятельств; процесс с оздания и консолидации нации есть длительным и весомым, наполненным историческими событиями и национальными культурными знаками.

Примордиалистские концепции остаются единодушными в признании исключительной важности психологических факторов в создании нации. Авторы исследуют сложный комплекс лигвистических, этнических, территориальных и мифобытовых факторов, которые определяют формирование соответствующего типа общества. Основой аналитики явления нации есть не только психологические, а и социальные, культурные, политические, этнические, моральные и аксиологические аспекты. Новое обсуждение концепции системы базируется на таких понятих, как солидарность, габитус, плебисцит, которыми было дополнено обсуждение нации. Обзор этих факторов свидетельствует, что невозможно осуществить сужение явдения нации к конкретной проблемной сфере и локализировать ее на инвариантные показатели. Формирование и оптимизация капиталистического типа социальной системы рождает новые факторы в интерпретации и консолидации нации.

В статье также рассматривается строительство нации в контексте международной и государственной политики как ключевое задание и определяются консолидирующий и дезинтегрирующий тип влияния государственной и межлддународной политики на процесс нациестроительства.

Причины политического поражения в развитии нации следует назвать либо сознательной манипулятивной техникой, или спонтанным просчетом.Разработка альтерантивных вариантов истории - это нечто другое, чем неоправданная политизация, реализация имперских или колониальных амбиций, преодоление которых есть необходимым условием успешного государственного строительства. У ставновление и компенсация манипулятивного влияния содействуют стабилизации 
соцыиальнйо ситупации и урегулирвоанию конфликтов, и таким образом национальному развитию.

Ключевым моментом здесь есть создание нации в рамках международной и государственной политики, оосбенно путем разграничения консолидирующих и дезинтегрирующих влияний государственной и международной политики на национальное строительство. Политика объединения нации может стать эффективной, когда важные реформы не углубляют фрагментацию нации, а только нейтрализуют ее.

Ключевые слова: примордиалистский подход, нация, консолидация, этнические группы, национальные общности.

Стаття рекомендована до публікації д.філософ.н., проф. (Козловецьь М.А., Житомир)

Надійшла до редколегіï: 12.09.2018

Прийнята до друку: 17.09.2018 